\title{
In vivo oocyte developmental competence is reduced in lean but not in obese superovulated dairy cows after intraovarian administration of IGF1
}

\author{
Miguel A Velazquez ${ }^{1,2}$, Klaus-Gerd Hadeler ${ }^{1}$, Doris Herrmann ${ }^{1}$, Wilfried A Kues ${ }^{1}$, \\ Susanne Ulbrich ${ }^{3}$, Heinrich H D Meyer ${ }^{3}$, Benoît Rémy ${ }^{4}$, Jean-François Beckers ${ }^{4}$, \\ Helga Sauerwein ${ }^{5}$ and Heiner Niemann ${ }^{1}$ \\ ${ }^{1}$ Department of Biotechnology, Institute of Farm Animal Genetics, Friedrich-Loeffler-Institut (FLI), Höltystrasse 10 \\ Mariensee, 31535 Neustadt, Germany, ${ }^{2}$ Escuela Superior de Ciencias Agropecuarias, Universidad Autónoma de \\ Campeche, Calle 53s/n, C.P. 24350 Escárcega, Campeche, Mexico, ${ }^{3}$ Physiology Weihenstephan, Technische \\ Universität München, Weihenstephaner Berg 3, 85354 Freising, Germany, ${ }^{4}$ Laboratory of Endocrinology and Animal \\ Reproduction, Faculty of Veterinary Medicine, University of Liege, B-4000 Liege, Belgium and ${ }^{5}$ Physiology and \\ Hygiene Unit, Institute for Animal Science, University of Bonn, Katzenburgweg 7-9, 53115 Bonn, Germany
}

Correspondence should be addressed to H Niemann; Email: heiner.niemann@fli.bund.de

\begin{abstract}
The present study investigated the role of IGF1 in lactating lean and non-lactating obese dairy cows by injecting $1 \mu \mathrm{g}$ IGF1 into the ovaries prior to superovulation. This amount of IGF1 has been linked with pregnancy loss in women with the polycystic ovary syndrome (PCOS) and was associated with impaired bovine oocyte competence in vitro. Transcript abundance and protein expression of selected genes involved in apoptosis, glucose metabolism, and the IGF system were analyzed. Plasma concentrations of IGF1 and leptin, and IGF1 in uterine luminal fluid (ULF), were also measured. IGF1 treatment decreased embryo viability in lean cows to the levels observed in obese cows. Obese cows were not affected by IGF1 treatment and showed elevated levels of IGF1 (in both plasma and ULF) and leptin. Blastocysts from lean cows treated with IGF1 showed a higher abundance of SLC2A1 and IGFBP3 transcripts. IGF1 treatment reduced protein expression of tumor protein 53 in blastocysts of lean cows, whereas the opposite was observed in obese cows. IGF1 in plasma and ULF was correlated only in the control groups. Blastocyst transcript abundance of IGF1 receptor and IGFBP3 correlated positively with IGF1 concentrations in both plasma and ULF in lean cows. The detrimental microenvironment created by IGF1 injection in lean cows and the lack of effect in obese cows resemble to a certain extent the situation observed in PCOS patients, where IGF1 bioavailability is increased in normal-weight women but reduced in obese women, suggesting that this bovine model could be useful for studying IGF1 involvement in PCOS.

Reproduction (2011) 142 41-52
\end{abstract}

\section{Introduction}

The insulin-like growth factor (IGF) system is critical for ovarian function (Kwintkiewicz \& Giudice 2009) and is an important signaling mechanism disrupted by hyperinsulinemia in women with the polycystic ovary syndrome (PCOS; Essah et al. 2004). High insulin concentrations reduce synthesis of IGF binding proteins such as IGFBP1, which in turn enhances the bioactivity of IGF1 (Thierry van Dessel et al. 1999, Wang \& Chard 1999). In vivo and in vitro rodent models demonstrated that exposing embryos to supraphysiological concentrations of IGF1 can result in abnormal preimplantation embryo development (Katagiri et al. 1996, 1997). This led to the hypothesis of a link between high levels of IGF1 and early pregnancy loss in PCOS women
(Chi et al. 2000, Eng et al. 2007, Pinto et al. 2002). The murine PCOS model was used to test the effects of supraphysiological concentrations of IGF1 during in vitro preimplantation embryo development (Chi et al. 2000, Pinto et al. 2002, Moley et al. 2005, Eng et al. 2007) but studies investigating in vivo oocyte developmental competence are lacking. In vitro oocyte developmental competence was reduced after nutrientinduced maternal hyperinsulinemia of bovine oocyte donors, similar to the insulin values observed in PCOS patients (Adamiak et al. 2005). The bovine female has been proposed as an in vivo bioassay for the generation of conceptual models relevant to ovarian function in women (Adams \& Pierson 1995) and has played a pivotal role in the development of an in vivo culture system 
for human embryos (Blockeel et al. 2009). Recently, the superovulated bovine female was proposed as an alternative animal model to investigate the endocrinerelated pathologies associated with IGF1 such as PCOS (Velazquez et al. 2009). In fact, the nymphomaniac cow has been considered as the only naturally occurring animal model for PCOS (Abbott et al. 2006).

The goal of the present study was to evaluate the effects of priming ovaries with intraovarian injections of IGF1 upon the superovulatory response of lactating lean and non-lactating obese dairy cows, as the bioavailability of IGF1 seems to be increased in normal-weight PCOS women but reduced in obese PCOS patients (Silfen et al. 2003, Premoli et al. 2005, Pasquali \& Gambineri 2008). IGF1 $(1 \mu \mathrm{g})$ was injected into the ovarian stroma, similar to the concentrations suggested to be present in PCOS women experiencing early pregnancy loss (i.e. 950-1500 ng/ml; Chi et al. 2000, Eng et al. 2007, Pinto et al. 2002) and associated with detrimental effects on bovine oocyte competence in vitro (Thomas et al. 2007). We used the bovine model established in our laboratory in which we have shown that an intraovarian injection of IGF1 affects mRNA expression of oocytes recovered by ovum pick-up, indicating that the IGF1 injected indeed reaches the oocyte in the ovarian follicle (Oropeza et al. 2004, Zaraza et al. 2010). It was intended to mimic the intraovarian milieu to which oocytes are exposed during the final stages of ovarian follicular development in women with PCOS. Embryo yields were determined and the resultant blastocysts were analyzed for specific characteristics related to the IGF pathway, including protein expression of the IGF1 receptor (IGF1R) and tumor protein 53 (TP53 gene), and transcript abundance of selected genes involved in apoptosis, glucose metabolism, and the IGF system. Furthermore, concentrations of IGF1 in plasma and non-diluted uterine luminal fluid (ULF) were measured.

\section{Results}

\section{Superovulatory response}

In the first trial, lean cows treated with IGF1 had a significantly reduced rate of viable embryos and an increased rate of degenerated embryos compared with the control group (Fig. 1). None of the superovulatory parameters was affected by IGF1 treatment in obese cows in both trials (Fig. 1 and Table 1). Parameters of embryo viability were similar between IGF1-treated lean cows and obese cows (Fig. 1). Lean control cows had a higher viability rate compared with obese cows treated with IGF1 (Fig. 1). The rate of degenerated embryos was lower in the control group of lean cows compared with the rest of the groups (Fig. 1). Most of the numerical parameters (e.g. number of viable embryos) of superovulatory response were higher in lean control cows
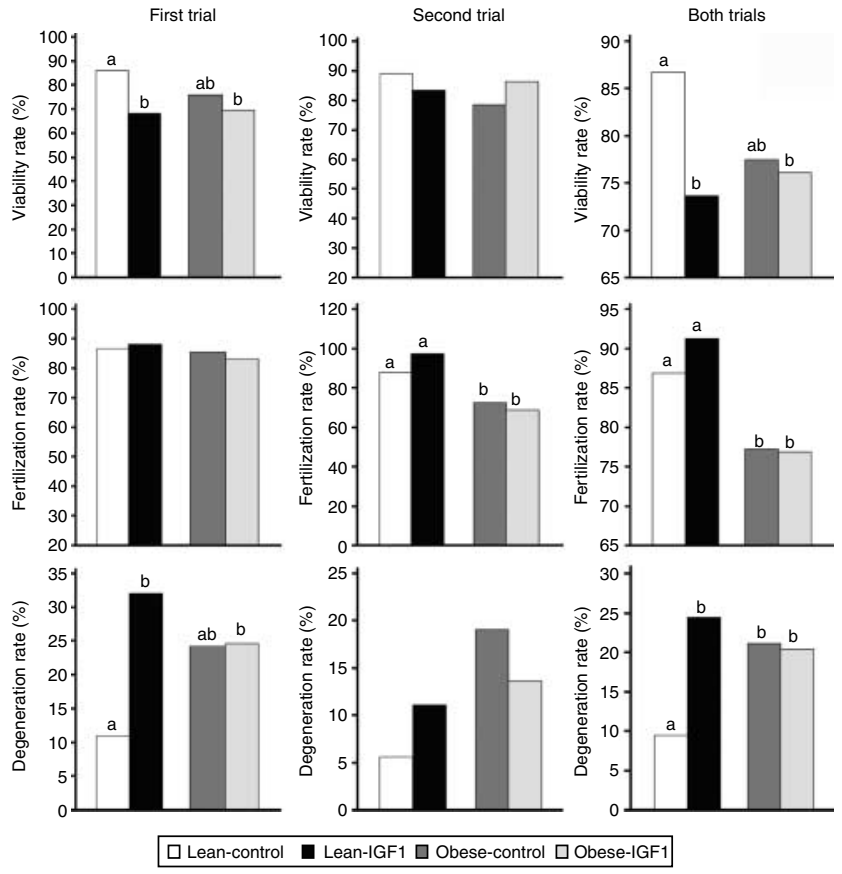

Figure 1 Effect of intraovarian application of $1 \mu \mathrm{g}$ IGF1 on selected parameters of superovulatory response expressed as proportions in lactating lean and non-lactating obese cows. Within trials, bars with different superscripts indicate a significant difference $(P \leq 0.05)$.

compared with obese cows (Table 1). Bovine superovulatory outcome can be compromised by lactation (Leroy et al. 2005), but the superovulatory response in control animals of this study was strongly related to the energy status of donors (reflected in their body condition score (BCS)) and not to lactation status per se, as lactating cows (lean animals) displayed a high production of viable embryos compared to non-lactating cows (obese animals).

\section{mRNA transcript expression}

Blastocysts from lean cows treated with IGF1 showed significantly increased expression of IGFBP3 and SLC2A1 compared with their control counterparts (Fig. 2). Transcript abundance of embryos from obese cows was not affected by IGF1 treatment. Blastocysts from lean cows treated with IGF1 expressed more IGFBP3 transcripts than blastocysts collected from IGF1-treated obese cows (Fig. 2). Blastocysts from lean cows treated with IGF1 also expressed more SLC2A1 transcripts than blastocysts collected from control obese cows (Fig. 2).

\section{IGF1R immunofluorescence}

IGF1R was localized to the cell membrane and the cytoplasm in both the inner cell mass (ICM) and trophectoderm (TE) in all embryos analyzed (Fig. 3). There were no significant differences in relative signal 
Table 1 Effects of intraovarian application of $1 \mu \mathrm{g}$ IGF1 on the superovulatory response of lean lactating and obese non-lactating cows (summary of both trials).

\begin{tabular}{|c|c|c|c|c|c|c|c|}
\hline \multirow[b]{2}{*}{ Parameter $^{\mathrm{a}}$} & \multicolumn{2}{|c|}{ Lean cows } & \multirow[b]{2}{*}{$P$} & \multirow{2}{*}{$\begin{array}{c}\text { Differences between } \\
\text { groups } \\
\boldsymbol{P}\end{array}$} & \multicolumn{2}{|c|}{ Obese cows } & \multirow[b]{2}{*}{$P$} \\
\hline & Control $(23)^{b}$ & IGF1 $(24)^{b}$ & & & Control $(15)^{b}$ & IGF1 $(21)^{b}$ & \\
\hline Corpora lutea $(\mathrm{CL})$ & $\begin{array}{l}14.9 \pm 1.5 \\
15.0(8.5-19.2)\end{array}$ & $\begin{array}{l}11.3 \pm 1.6 \\
9.5(5.5-17.0)\end{array}$ & 0.128 & $\begin{array}{c}A=0.004 ; B=0.309 \\
C=0.008 ; D=0.183\end{array}$ & $\begin{array}{l}8.2 \pm 1.1 \\
8.0(4.2-11.0)\end{array}$ & $\begin{array}{l}9.1 \pm 1.2 \\
10.0(4.7-12.2)\end{array}$ & 0.613 \\
\hline Ova +embryos & $\begin{array}{l}13.2 \pm 1.7 \\
13.0(5.2-19.2)\end{array}$ & $\begin{array}{l}9.0 \pm 1.8 \\
6.0(1.0-15.5)\end{array}$ & 0.111 & $\begin{array}{c}\mathrm{A}=0.007 ; \mathrm{B}=0.731 \\
\mathrm{C}=0.010 ; \mathrm{D}=0.563\end{array}$ & $\begin{array}{l}6.1 \pm 1.3 \\
6.0(1.2-10.5)\end{array}$ & $\begin{array}{l}7.0 \pm 1.3 \\
5.0(2.7-11.0)\end{array}$ & 0.665 \\
\hline Embryos & $\begin{array}{l}11.4 \pm 1.7 \\
10.0(4.0-17.0)\end{array}$ & $\begin{array}{l}8.2 \pm 1.7 \\
5.0(1.0-15.0)\end{array}$ & 0.116 & $\begin{array}{l}\mathrm{A}=0.007 ; \mathrm{B}=0.458 \\
\quad \mathrm{C}=0.005 ; \mathrm{D}=0.311\end{array}$ & $\begin{array}{l}4.7 \pm 1.2 \\
2.0(1.0-7.7)\end{array}$ & $\begin{array}{l}5.3 \pm 1.0 \\
4.0(2.0-9.2)\end{array}$ & 0.647 \\
\hline Viable embryos & $\begin{array}{l}9.9 \pm 1.5 \\
10.0(4.0-14.7)\end{array}$ & $\begin{array}{l}6.0 \pm 1.4 \\
3.5(0.0-11.0)\end{array}$ & 0.033 & $\begin{array}{l}\mathrm{A}=0.006 ; \mathrm{B}=0.262 ; \\
\mathrm{C}=0.004 ; \mathrm{D}=0.412\end{array}$ & $\begin{array}{l}3.6 \pm 1.0 \\
1.0(0.0-6.0)\end{array}$ & $\begin{array}{l}4.0 \pm 0.8 \\
3.0(0.7-6.5)\end{array}$ & 0.603 \\
\hline Quality 1 embryos & $\begin{array}{l}7.3 \pm 1.1 \\
6.0(3.2-12.7)\end{array}$ & $\begin{array}{l}4.6 \pm 1.1 \\
3.5(0.0-7.5)\end{array}$ & 0.041 & $\begin{array}{l}\mathrm{A}=0.009 ; \mathrm{B}=0.254 \\
\mathrm{C}=0.004 ; \mathrm{D}=0.286\end{array}$ & $\begin{array}{l}3.0 \pm 0.8 \\
1.0(0.0-5.7)\end{array}$ & $\begin{array}{l}3.0 \pm 0.7 \\
2.0(0.0-6.0)\end{array}$ & 0.936 \\
\hline Quality 2 embryos & $\begin{array}{l}2.6 \pm 0.6 \\
1.0(0.0-4.0)\end{array}$ & $\begin{array}{l}1.3 \pm 0.4 \\
0.0(0.0-2.5)\end{array}$ & 0.153 & $\begin{array}{c}\mathrm{A}=0.030 ; \mathrm{B}=0.820 \\
\mathrm{C}=0.097 ; \mathrm{D}=0.277\end{array}$ & $\begin{array}{l}0.6 \pm 0.4 \\
0.0(0.0-0.0)\end{array}$ & $\begin{array}{l}1.0 \pm 0.3 \\
0.0(0.0-0.2)\end{array}$ & 0.318 \\
\hline Quality 3 embryos & $\begin{array}{l}0.4 \pm 0.2 \\
0.0(0.0-0.0)\end{array}$ & $\begin{array}{l}0.1 \pm 0.1 \\
0.0(0.0-0.0)\end{array}$ & 0.756 & $\begin{array}{l}\mathrm{A}=0.718 ; \mathrm{B}=0.757 \\
\mathrm{C}=0.991 ; \mathrm{D}=0.930\end{array}$ & $\begin{array}{l}0.6 \pm 0.6 \\
0.0(0.0-0.0)\end{array}$ & $\begin{array}{l}0.1 \pm 0.1 \\
0.0(0.0-0.0)\end{array}$ & 0.697 \\
\hline Morulae & $\begin{array}{l}3.8 \pm 0.8 \\
3.0(0.0-7.7)\end{array}$ & $\begin{array}{l}3.1 \pm 0.8 \\
1.0(0.0-5.5)\end{array}$ & 0.406 & $\begin{array}{l}\mathrm{A}=0.075 ; \mathrm{B}=0.624 ; \\
\mathrm{C}=0.126 ; \mathrm{D}=0.394\end{array}$ & $\begin{array}{l}1.5 \pm 0.5 \\
0.0(0.0-3.2)\end{array}$ & $\begin{array}{l}1.8 \pm 0.5 \\
1.0(0.0-3.2)\end{array}$ & 0.585 \\
\hline Blastocysts & $\begin{array}{l}6.5 \pm 1.3 \\
5.0(1.0-11.2)\end{array}$ & $\begin{array}{l}3.0 \pm 0.8 \\
0.5(0.0-5.5)\end{array}$ & 0.040 & $\begin{array}{l}\mathrm{A}=0.017 ; \mathrm{B}=0.900 \\
\mathrm{C}=0.027 ; \mathrm{D}=0.654\end{array}$ & $\begin{array}{l}2.1 \pm 0.9 \\
0.0(0.0-3.5)\end{array}$ & $\begin{array}{l}2.4 \pm 0.6 \\
2.0(0.0-4.0)\end{array}$ & 0.480 \\
\hline Degenerated embryos & $\begin{array}{l}1.0 \pm 0.4 \\
0.0(0.0-1.0)\end{array}$ & $\begin{array}{l}2.0 \pm 0.6 \\
0.5(0.0-3.0)\end{array}$ & 0.388 & $\begin{array}{l}\mathrm{A}=0.600 ; \mathrm{B}=0.592 ; \\
\mathrm{C}=0.742 ; \mathrm{D}=0.729\end{array}$ & $\begin{array}{l}1.0 \pm 0.3 \\
1.0(0.0-2.0)\end{array}$ & $\begin{array}{l}1.0 \pm 0.3 \\
0.0(0.0-2.0)\end{array}$ & 0.860 \\
\hline Unfertilized ova & $\begin{array}{l}1.7 \pm 0.6 \\
0.0(0.0-1.7)\end{array}$ & $\begin{array}{l}0.7 \pm 0.4 \\
0.0(0.0-1.0)\end{array}$ & 0.382 & $\begin{array}{l}A=0.753 ; B=0.368 ; \\
C=0.991 ; D=0.183\end{array}$ & $\begin{array}{l}1.4 \pm 0.4 \\
1.0(0.0-2.7)\end{array}$ & $\begin{array}{l}1.6 \pm 0.6 \\
0.0(0.0-2.0)\end{array}$ & 0.664 \\
\hline
\end{tabular}

$\mathrm{A}=$ lean control $(\mathrm{L}-\mathrm{C})$ versus obese control (O-C), B = lean IGF1 (L-IGF1) versus obese IGF1 (O-IGF1), C=L-C versus O-IGF1, D=L-IGF1 versus O-C. ${ }^{\mathrm{a}}$ Reported as mean \pm s.E.M. and median (first quartile to third quartile). ${ }^{\mathrm{b}}$ Analysis was carried out only in cows that responded to superovulation (i.e. two or more $C L$ at the time of embryo recovery).

strength (RSS) values between the ICM and TE in blastocysts from lean cows. In the obese group, only blastocysts from control cows showed less IGF1R in the ICM (Fig. 4). IGF1 treatment did not affect blastocyst IGF1R expression in any of the groups. Embryos from lean cows had a higher protein expression of the IGF1R than those from obese control cows (Fig. 4). Blastocysts collected from obese cows treated with IGF1 and lean control animals did not show significant differences. However, embryos from IGF1-treated lean cows displayed a higher IGF1R expression compared with embryos from obese cows treated with IGF1 (Fig. 4).

\section{TP53 immunofluorescence}

All embryos showed cell membrane and cytoplasmic localization of TP53 in both the ICM and the TE (Fig. 3). No differences in RSS values were detected between the ICM and TE in any of the groups. In the lean group, blastocysts from cows treated with IGF1 showed a reduced expression of TP53 protein compared with controls. In contrast, in obese animals, blastocysts from IGF1-treated cows displayed an increased TP53 expression compared with controls (Fig. 4). Embryos from lean control cows had more TP53 than embryos from obese cows (Fig. 4). Blastocysts collected from lean cows treated with IGF1 expressed more TP53 than those from obese control cows, but showed a lower TP53 expression than blastocysts from obese IGF1-treated cows (Fig. 4).

\section{Embryo cell number, concentrations of IGF1 in plasma and $U L F$, and plasma concentrations of leptin}

Blastocysts from lean control cows had more total cells than embryos from the other groups (Table 2). Intraovarian application of IGF1 did not affect plasma or ULF IGF1 concentrations in any of the groups. Obese cows showed higher concentrations of IGF1 in plasma compared with lean cows. The same was observed for IGF1 concentrations in ULF but only in the control groups (Table 2). Plasma and ULF IGF1 concentrations correlated only in the control groups (lean cows: $r=0.516, r^{2}=0.23 \%$, $P=0.014$; obese cows: $r=0.712, r^{2}=0.54 \%, P=0.002$ ). IGF1 concentrations in plasma and ULF were correlated with the expression of IGF1R (plasma: $r=0.502$, $r^{2}=0.20 \%, P=0.034 ;$ ULF: $r=0.554, r^{2}=0.26 \%$, $P=0.017$ ) and IGFBP3 (plasma: $r=0.476, r^{2}=0.17 \%$, $P=0.046 ;$ ULF: $\left.r=0.625, r^{2}=0.35 \%, P=0.006\right)$ in blastocysts collected from lean control cows. For both genes, the correlation was stronger with IGF1 concentrations in ULF. Leptin concentrations in plasma were not affected by IGF1 treatment in any of the groups (Table 3). However, the obese cows displayed higher plasma concentrations of leptin than did the lean cows (Table 3).

\section{Discussion}

The main finding of the present study is the negative effect of intraovarian application of IGF1 on oocyte developmental competence observed exclusively in lean 

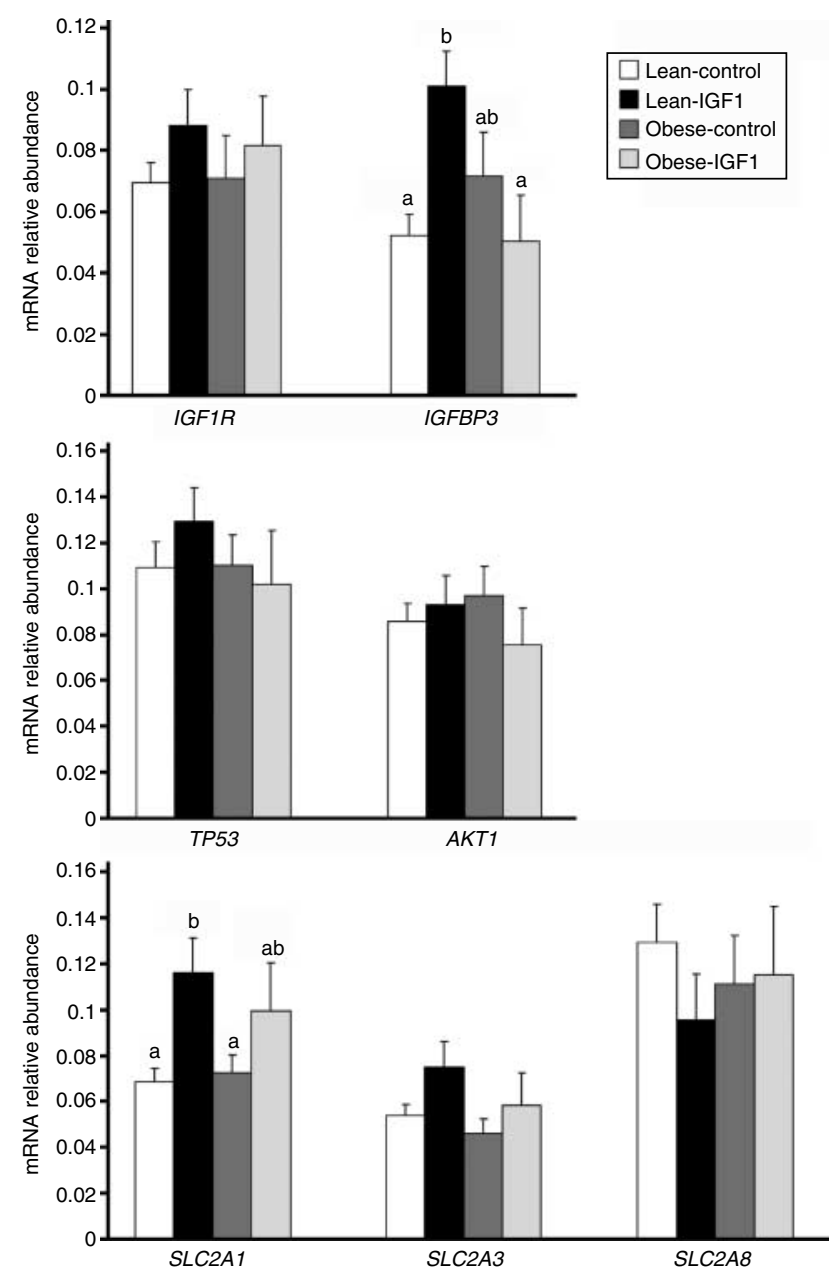

obese cows that should have higher concentrations of IGF1. However, this was not the case. In vitro experiments have demonstrated that high concentrations of leptin can suppress the stimulatory effects of IGF1 upon steroidogenesis in ovarian follicular cells from rats (Zachow \& Magoffin 1997), humans (Agarwal et al. 1999, Huang et al. 2005, Karamouti et al. 2008), and cattle (Spicer et al. 2000). Based on these findings, we choose to analyze leptin levels as a starting point to elucidate why the IGF1 treatment did not affect the superovulatory response in obese cows. The effects of exogenous IGF1 on ovarian follicles were probably partially neutralized by leptin in obese cows. Nevertheless, this hypothesis requires further study, including the underlying mechanism of the neutralizing effect of leptin on IGF1 action. This could involve reduced expression of the IGF1R, as ovarian follicular gene expression of the IGF1R can be decreased after in vivo infusion of pharmacological doses of leptin in ruminants (Muñoz-Gutiérrez et al. 2005). In the present study, blastocysts from obese control cows displayed reduced protein expression of the IGF1R compared with lean control cows.

To our knowledge, this is the first report providing in vivo evidence that IGF1 can upregulate its receptor

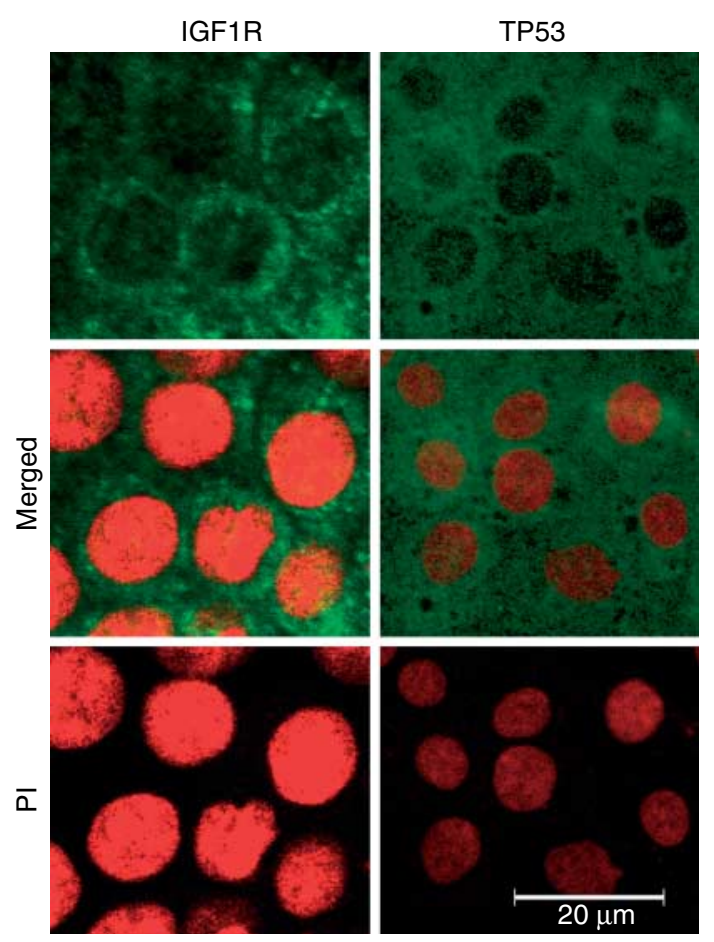

Figure 2 Relative transcript abundance (mean \pm S.E.M.) of developmentally important genes in blastocysts collected from control and IGF1-treated lactating lean and non-lactating obese superovulated cows. Bars with different superscripts within each gene transcript indicate a significant difference $(P \leq 0.05)$. Each analysis was replicated 7-18 times.

lactating cows, which could at least be partially explained by interactions of IGF1 with other hormones of reproductive importance, such as leptin. As previously reported (Ehrhardt et al. 2000, Adamiak et al. 2005), obese cows in the present study had higher leptin concentrations in blood than their lean counterparts. A positive correlation between bovine leptin levels in blood and follicular fluid has been documented (Dayi et al. 2005). The hormonal differences between lean and obese cows were expected, as it is well documented that IGF1 and leptin are closely associated with BCS (Ehrhardt et al. 2000, Velazquez et al. 2008). Our hypothesis was that an oocyte in a microenvironment with no deficits of IGF1 (lean cows out of the phase of negative energy balance) will be negatively affected by inducing a short high IGF1 microenvironment similar to the one present in PCOS women. Therefore, a marked detrimental effect of IGF1 treatment was expected in 

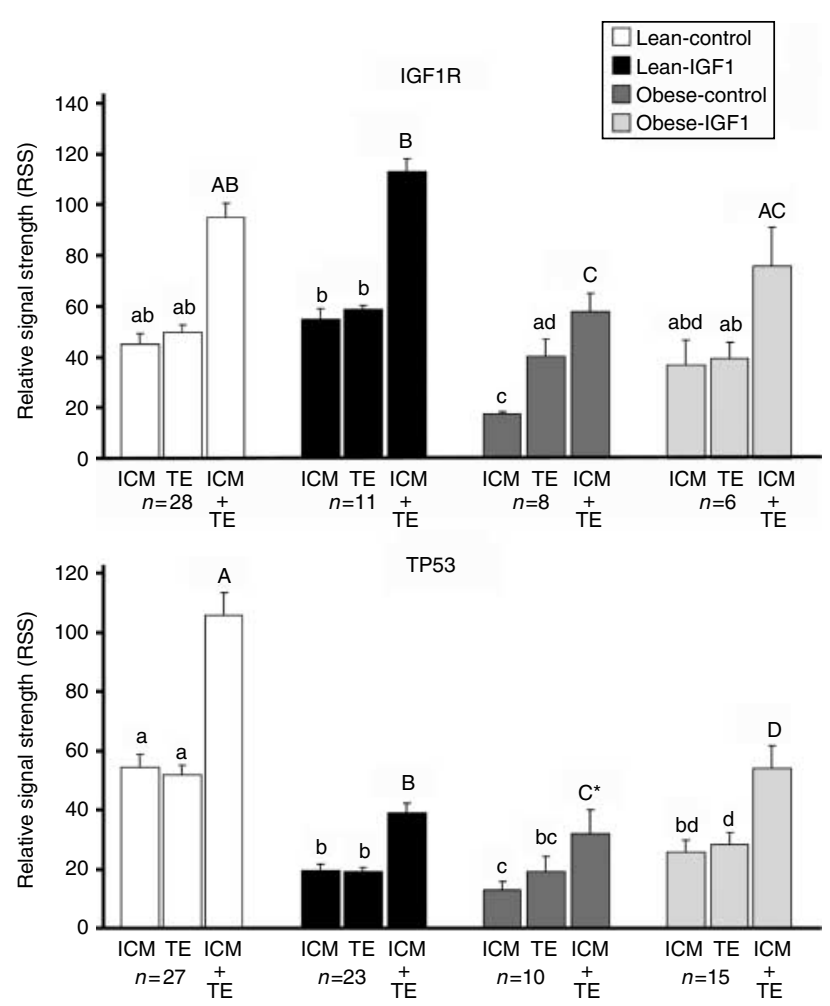

Figure 4 Differences $(P \leq 0.05)$ in relative signal strength (RSS) values (mean \pm s.E.M.) of IGF1R and TP53 in blastocysts collected from control and IGF1-treated lactating lean and non-lactating obese superovulated cows. Bars with different small superscripts (a, b, c, and d) indicate significant differences between the inner cell mass (ICM) and trophectoderm (TE) within groups (control or IGF1 (ICM versus TE)), and differences between groups (control versus IGF1) within categories (lean or obese cows) in the same cell compartment (ICM versus ICM; TE versus TE). Small superscripts also indicate differences in the same cell compartment (ICM versus ICM; TE versus TE) between lean and obese cows. Significant differences in total RSS values are indicated by capital superscripts (A, B, C, and D). *Significance obtained with Mann-Whitney $U$ test (B versus $C$ ).

and one of its binding proteins in bovine preimplantation embryos. The coefficients of determination were relatively low, but not unexpected as transcript expression of these genes is also regulated by steroids, gonadotropins and other growth factors (Sepp-Lorenzino 1998, Firth \& Baxter 2002). However, this relationship was only detected in lean cows not treated with IGF1. These cows also showed the highest yield of viable embryos and lowest proportion of degenerated embryos. This observation implies that subtle disruptions in the delicate balance of components in the ULF can be sufficient to interfere with preimplantation embryo development. An in-depth study of this relationship (i.e. correlation between embryo gene expression and hormonal concentrations in blood and ULF=optimal embryo development) could provide clues to identify the optimal uterine microenvironment for preimplantation embryo development. Our data also showed that, after intraovarian IGF1 application, the correlation between
IGF1 concentrations in plasma and ULF was lost. The reason for this is unknown, but it is possible that some of the injected IGF1 could have reached the oviducts and uterus via counter-current transfer (Einer-Jensen \& Hunter 2005) and altered the transport of IGF1 across oviductal and uterine tissues, probably by altering vascular permeability (Nasu et al. 2006). Accordingly, as few as seven small IGF1-loaded beads placed into the uterine lumen of mice were capable of inducing changes in endometrial vascular permeability (Paria et al. 2001). Transfer from the ovary to oviducts and uterus could have occurred within seconds or minutes (Einer-Jensen \& Hunter 2005) after IGF1 administration and was probably exacerbated in our model, as blood flow in reproductive tract is dramatically increased by superovulation (Honnens et al. 2009).

The present study confirmed the known adverse effects of obesity upon mammalian reproduction (Brewer \& Balen 2010) and revealed that intraovarian application of high amounts of IGF1 in lean cows can decrease embryo viability to the levels observed in obese cows. We recently reported that intraovarian administration of $6 \mu \mathrm{g}$ IGF1 reduced blastocyst yields of cycling young heifers subjected to ovum pick-up and IVF compared with mock-treated control animals (Zaraza et al. 2010). In this model, the heifers were still growing and endogenous concentrations of IGF1 were probably higher than in their adult counterparts, with no deficit of IGF1, unless they are under a catabolic disease state (Velazquez et al. 2008). Our results also agree with previous studies carried out in women (Wang et al. 2006) and heifers (Nicholas et al. 2005, Siddiqui et al. 2009), where oocytes obtained from follicles with high IGF1 bioavailability (i.e. more free IGF1 or less IGFBPs) displayed impaired developmental competence in vitro. In vitro studies have shown that exposing bovine follicles to a high IGF1 microenvironment leads to reduced oocyte size and a decreased number of granulosa cells (McCaffery et al. 2000, Thomas et al. 2007). A recent in vivo experiment showed that intrafollicular injection of $200 \mu \mathrm{g}$ IGF1 in the second largest ovarian follicle decreased the growth rate and maximum diameter of the largest follicle (Shahiduzzaman et al. 2010). All these features are known to have negative consequences for meiotic maturation, fertilization, and development to the blastocyst stage (Fair et al. 1995, Arlotto et al. 1996, Otoi et al. 1997). Results of the present investigation also indicate that oocyte competence can be compromised by a relatively short exposure to high levels of IGF1. Similarly, short-term treatment $(9 \mathrm{~h})$ with physiological concentrations of IGF1 (100 ng/ml) was enough to block heat shock-induced apoptosis in preimplantation bovine embryos (Jousan et al. 2008). Experiments in humans and ruminants revealed that unbound IGF1 has a half-life of $\sim 12 \mathrm{~min}$, but it can be prolonged up to several hours when linked to binding proteins (Guler et al. 1989, Basset et al. 1990). Accordingly, IGFBPs can 


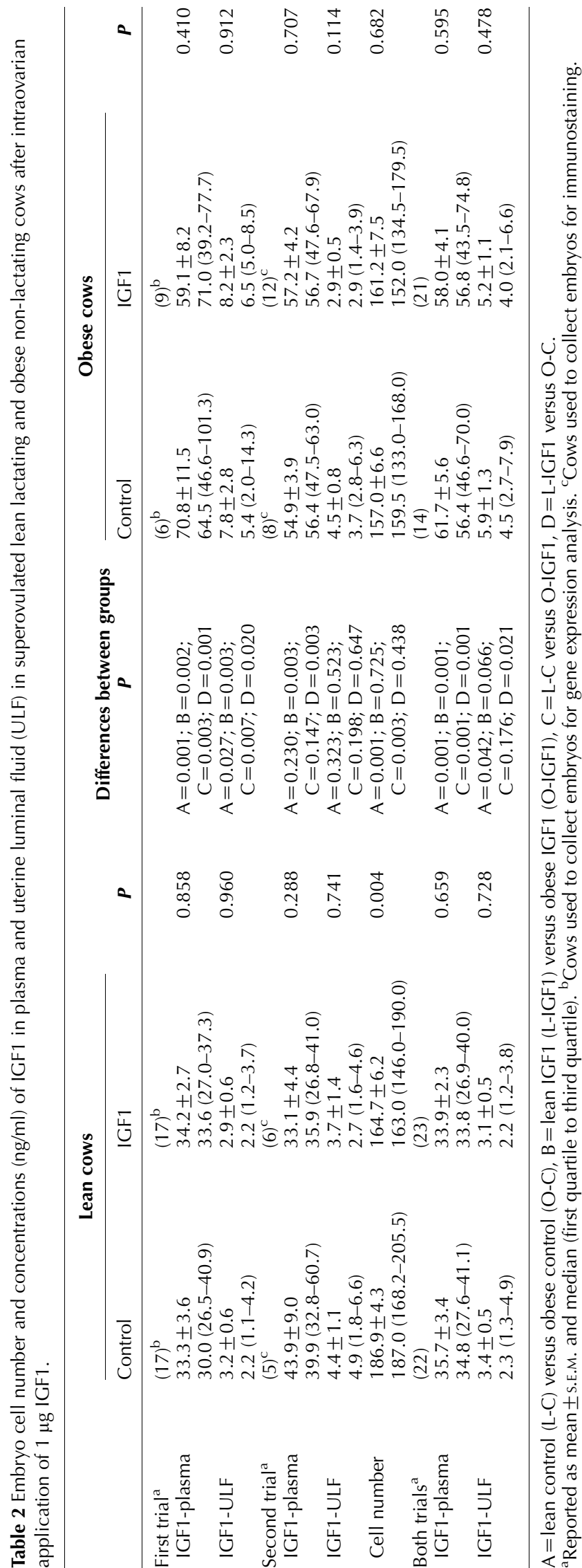

retain IGF1 in the apical region of bovine endothelial cells, controlling localized delivery of IGF1 (Paye \& Forsten-Williams 2006). In the present study, the milieu of the oocyte affected not only development to blastocysts but also the molecular and cellular parameters measured at the blastocyst stage. Similar long-term effects have been previously reported. For instance, a short (30 min) exposure of pig oocytes to bovine oviductal fluid induced changes in the cell number and gene expression at the blastocyst stages (Lloyd et al. 2009).

Whether the raised expression of SLC2A1 (formerly known as GLUT1) and IGFBP3 detected in blastocysts from lean cows treated with IGF1 is indicative of impaired embryo quality is unknown at present. Expression of SLC2A1 was not different between in vivo- and in vitro-produced embryos, even though a significant reduction in pregnancy rates was observed with in vitro-produced embryos (Lazzari et al. 2002). Bertolini et al. (2002) found that in vivo-derived embryos showed an increased transcript abundance of SLC2A1 compared with embryos produced in vitro. In contrast, Rho et al. (2007) reported higher expression of $S L C 2 A 1$ in in vitro-derived embryos compared with their in vivo counterparts and suggested that this was an adaptive response due to altered metabolism. However, this adaptive response might not necessarily represent a decline in quality as shown by the upregulation of SLC2A1 in blastocysts derived from a defined in vitro medium capable of having similar calving rates as those from in vivo embryos (Lim et al. 2007). The available information on IGFBP3 indicates that in vivo-derived embryos expressed more IGFBP3 transcripts than in vitro-produced embryos (Sawai 2009). TP53 expression plays a role in cell cycle arrest and apoptosis in tumor cells (Rodier et al. 2007), and activation of TP53 has been proposed to be indicative of embryo demise (Keim et al. 2001, Matwee et al. 2001). However, recent information suggests that TP53 is critical for successful development, as the primordial function of its ancestor gene was to ensure fecundity and production of normal offspring, and its function as tumor suppressor came later in evolution (Hu 2009). For instance, expression of TP53 is essential for female fertility (Hu et al. 2007) and active TP53-dependent cell death signaling is required to suppress erroneous replication of damaged DNA during the preimplantation period (Toyoshima 2009) and to avoid abnormalities during fetal development (Torchinsky \& Toder 2010). In fact, normal cellular differentiation during murine embryogenesis has been associated with increased expression of TP53 (Schmid et al. 1991). From this perspective, the low levels of TP53 protein in blastocyst from lean cows treated with IGF1 could indicate reduced embryo quality, whereas the opposite could be implied in obese cows, as embryos from IGF1-treated cows in this group displayed higher expression of TP53. 
Table 3 Concentrations $(\mathrm{ng} / \mathrm{ml})$ of leptin in plasma of superovulated lean lactating and obese non-lactating cows after intraovarian application of $1 \mu \mathrm{g}$ IGF1.

\begin{tabular}{|c|c|c|c|c|c|c|c|}
\hline & \multicolumn{2}{|c|}{ Lean cows } & \multirow[b]{2}{*}{$\boldsymbol{P}$} & \multirow{2}{*}{$\begin{array}{c}\text { Differences between } \\
\text { groups } \\
\boldsymbol{P}\end{array}$} & \multicolumn{2}{|c|}{ Obese cows } & \multirow[b]{2}{*}{$P$} \\
\hline & Control & IGF1 & & & Control & IGF1 & \\
\hline First trial $^{\mathrm{a}}$ & $(17)^{b}$ & $(17)^{b}$ & & & $(6)^{b}$ & $(9)^{b}$ & \\
\hline $\begin{array}{l}\text { Leptin-plasma } \\
\text { Second trial }\end{array}$ & $\begin{array}{l}5.1 \pm 0.4 \\
4.6(4.2-6.2) \\
(5)^{\mathrm{C}}\end{array}$ & $\begin{array}{l}5.1 \pm 0.4 \\
4.7(3.9-5.9) \\
(6)^{\mathrm{C}}\end{array}$ & 0.977 & $\begin{array}{l}A=0.001 ; B=0.001 \\
\quad C=0.001 ; D=0.001\end{array}$ & $\begin{array}{l}8.5 \pm 0.8 \\
9.1(6.5-9.8) \\
(8)^{\mathrm{c}}\end{array}$ & $\begin{array}{l}9.5 \pm 0.9 \\
10.3(7.4-10.7) \\
(12)^{\mathrm{c}}\end{array}$ & 0.461 \\
\hline Leptin-plasma & $\begin{array}{l}4.7 \pm 0.5 \\
4.4(3.7-5.7)\end{array}$ & $\begin{array}{l}4.3 \pm 0.1 \\
4.2(4.1-4.5)\end{array}$ & 0.931 & $\begin{array}{c}A=0.002 ; B=0.001 \\
C=0.030 ; D=0.001\end{array}$ & $\begin{array}{l}8.0 \pm 0.5 \\
8.1(6.6-9.3)\end{array}$ & $\begin{array}{l}8.0 \pm 0.8 \\
7.3(5.9-8.7)\end{array}$ & 0.999 \\
\hline Both trials ${ }^{a}$ & $(22)$ & $(23)$ & & & (14) & $(21)$ & \\
\hline Leptin-plasma & $\begin{array}{l}5.0 \pm 0.3 \\
4.5(4.1-6.2)\end{array}$ & $\begin{array}{l}4.9 \pm 0.3 \\
4.5(4.0-5.5)\end{array}$ & 0.829 & $\begin{array}{l}\mathrm{A}=0.001 ; \mathrm{B}=0.001 \\
\quad \mathrm{C}=0.001 ; \mathrm{D}=0.001\end{array}$ & $\begin{array}{l}8.2 \pm 0.4 \\
8.6(6.5-9.8)\end{array}$ & $\begin{array}{l}8.7 \pm 0.6 \\
8.1(6.1-10.6)\end{array}$ & 0.617 \\
\hline
\end{tabular}

$\mathrm{A}=$ lean control $(\mathrm{L}-\mathrm{C})$ versus obese control (O-C), B = lean IGF1 (L-IGF1) versus obese IGF1 (O-IGF1), C=L-C versus O-IGF1, D = L-IGF1 versus O-C. ${ }^{\mathrm{a}}$ Reported as mean \pm s.E.M. and median (first quartile to third quartile). ${ }^{\mathrm{b}}$ Cows used to collect embryos for gene expression analysis. ${ }^{\mathrm{c}} \mathrm{Cows}$ used to collect embryos for immunostaining.

This hypothesis on embryo quality needs to be substantiated with embryo transfer studies.

An important feature of this superovulated bovine model is that the detrimental microenvironment created by the intraovarian IGF1 injection in lean cows and the lack of effects in obese cows resemble to a certain extent the situation observed in PCOS, where IGF1 bioavailability is increased in normal-weight PCOS women, but reduced in obese PCOS patients (Silfen et al. 2003, Premoli et al. 2005, Pasquali \& Gambineri 2008). In a natural high IGF1 microenvironment such as PCOS, oocytes and preimplantation embryos will be exposed continuously to high concentrations of IGF1, possibly exacerbating the effects observed in the present study. Research in mice has shown that in vitro exposure of preimplantation embryos to high IGF1 concentrations results in increased apoptosis and resorption rates after transfer to recipients (Chi et al. 2000, Pinto et al. 2002, Eng et al. 2007). Increases in the number of apoptotic cells and aberrant cell allocation have been observed in in vitro-produced bovine blastocysts exposed to high IGF1 concentrations from the zygote stage onwards (Velazquez et al. 2011). Results from the present in vivo model and the available in vitro information strongly indicate that high IGF1 concentrations are detrimental to the establishment of pregnancy. This information is not only relevant for PCOS women, but also for individuals using GH (Sonksen 2001), IGF1 (Guha et al. 2009), or bovine colostrum (Shing et al. 2009) to improve physical performance.

In conclusion, oocyte developmental competence was reduced by a relatively short exposure to supraphysiological concentrations of IGF1 in lean cows to the levels observed in obese cows. Superovulated obese cows seem to be refractory to IGF1 at the ovarian level. The adverse consequences on oocyte competence in lean cows and the absence of effects in obese cows after IGF1 intraovarian administration resemble to a certain extent the situation observed in PCOS patients, where IGF1 bioavailability is increased in normal-weight
PCOS women, but reduced in obese PCOS patients. This supports our proposal of using the superovulated female bovine as an alternative model for research on reproductive disorders in humans associated with abnormal IGF1 concentrations (Velazquez et al. 2009). Overall, the present data suggest that conditions or therapies inducing excessive IGF1 signaling should be avoided during the periconceptual period in order to reduce the risk of an early pregnancy loss in monovulatory species such as cattle and humans.

\section{Materials and Methods}

\section{Animals}

The study was carried out in the experimental herds of the Institute of Farm Animal Genetics (FLI), Mariensee, Germany. A total of 33 lactating Holstein Friesian and 44 non-lactating Deutsche Schwarzbunte (DSB) cows were used as embryo donors. Lactating cows were fed a mixed ration and additional concentrate based on milk yield. All lactating cows (lean cows) were in mid-lactation and had a BCS (five-point scale of Edmonson et al. (1989) $1=$ emaciated and $5=$ grossly overfat) of 2.5-3.5. This is the recommended BCS range for this lactation period to ensure that animals are not in a negative energy balance (Chagas et al. 2007). Deutsche Schwarzbunte non-lactating cows (obese cows) were fed for maintenance requirements and had not been lactating for at least 6 months. These animals had a BCS $\geq 4$ (Fig. 5). Our experimental herd consists of Holstein cows that have in their genetic origin the Deutsche Schwarzbunte breed and in fact are crosses to various extents (50-100\%) with DSB. Our long-term records indicate that both types of cows (Holstein and DSB) do not show differences regarding embryo production when subjected to superovulation. The mean age of all cows was 4 years. All cows were kept in tie-stalls with water ad libitum. Animal experiments were performed according to the German law for the protection of animals. The study comprised of two trials, in the first trial (February-November 2008) animals (lactating $=19$ and non-lactating $=10$ ) were superovulated in a cross-over design and in the second trial (June-December 2009) a different set of animals (lactating $=14$ 


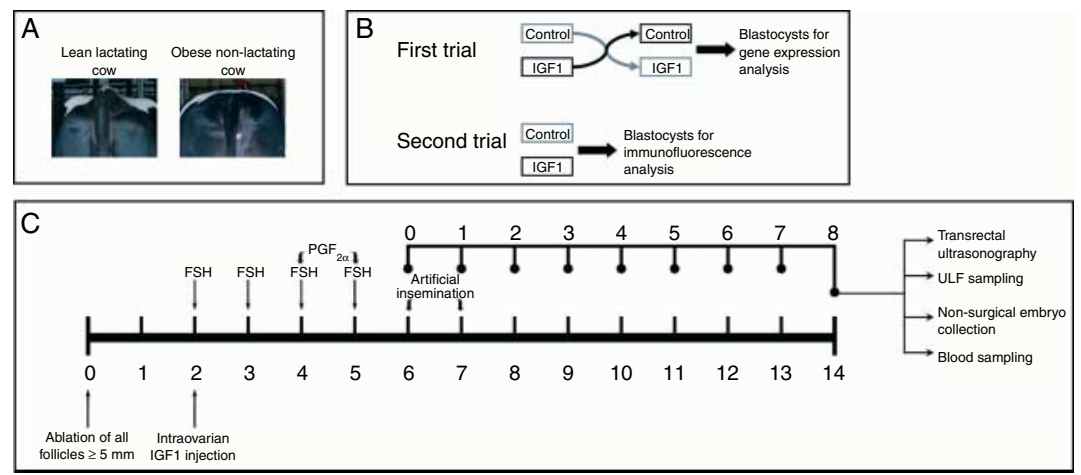

Figure 5 (A) Example of lactating lean and nonlactating obese cows used in this study. (B and C) Diagram showing animal allocation in both trials and experimental procedures performed in each cow (see text for details). and non-lactating $=34$ ) were superovulated either as controls or IGF1-treated cows (Fig. 5). In the second trial, in the lactating lean category, seven cows were used in each group (i.e. control or IGF1), whereas in the non-lactating obese category 16 and 18 cows were used in the control and the IGF1-treated group respectively.

\section{In vivo production of embryos}

All animals were cycling regularly prior to use in the experiments. Transvaginal ultrasound-guided ovum pick-up and intraovarian injections were performed as previously described (Oropeza et al. 2004). For each cow, the experimental period started with aspiration of all visible antral follicles $\geq 5 \mathrm{~mm}$ in both ovaries at unknown stages of the estrous cycle (day 0) (Baracaldo et al. 2000). Two days after follicle ablation, a single intraovarian injection of $1 \mu \mathrm{g}$ recombinant human IGF1 (291-G1; R\&D Systems, WiesbadenNordenstadt, Germany) diluted in $0.5 \mathrm{ml}$ PBS (A0964; AppliChem, Darmstadt, Germany) supplemented with $0.1 \%$ BSA (A9647, Sigma-Aldrich) was administered in the stroma of each ovary. Control animals received only $0.5 \mathrm{ml}$ PBS/BSA without IGF1. Any visible follicle with more than $4 \mathrm{~mm}$ in size on day 2 was aspirated immediately prior to intraovarian injection to ensure a homogenous population of follicles with 3-4 $\mathrm{mm}$ in diameter. Immediately after intraovarian treatment, cows entered a superovulatory regime with $500 \mu \mathrm{g}$ porcine FSH combined with $100 \mu$ g porcine LH (Stimufol; Ulg, FMV PhR, University of Liege, Sart-Tilmann, Belgium) in a total volume of $10 \mathrm{ml}$ administered i.m. in 8 decreasing doses over 4 days. A prostaglandin $\mathrm{F}_{2 \alpha}$ analog (Estrumate; Intervet, Unterscheißheim, Germany) was applied on days 4 (pm) and 5 (am) followed by artificial insemination (Al) on days 6 (pm) and 7 (am-pm). All cows were inseminated three times with the same bull of proven fertility for Al. Eight days after first insemination (day 14 of the experimental period) embryos were recovered by non-surgical uterine flushing with $500 \mathrm{ml}$ PBS supplemented with 1\% (v/v) newborn calf serum (B15-001; PAA Laboratories $\mathrm{GmbH}$, Pasching, Austria; Fig. 5). Prior to embryo recovery, the ovarian response (i.e. number of corpora lutea) was analyzed by transrectal ultrasonography (Bungartz \& Niemann 1994), followed by collection of non-diluted ULF samples, as recently described (Velazquez et al. 2010). Blood samples were collected immediately after embryo collection from the coccygeal vein into tubes containing EDTA (Greiner
Bio-one, Frickenhausen, Germany). Blood samples were centrifuged ( $2000 \mathrm{~g}$ for $20 \mathrm{~min}$ ) followed by plasma collection and storage at $-25^{\circ} \mathrm{C}$. Embryos were graded according to the IETS guidelines (Stringfellow \& Seidel 1998) and processed within $30 \mathrm{~min}$ after collection. To discriminate between oocytes and zygotes, presumptive oocytes were subjected to differential cell staining (Velazquez et al. 2011). Animals in the cross-over design (first trial) were submitted again to follicular ablation and superovulation after at least one normal estrous cycle. Blastocysts of quality 1 (Stringfellow \& Seidel 1998) collected from the first trial were used for gene expression analysis, whereas those collected in the second trial were used for immunostaining. All embryos were processed while maintaining the identity of the donor.

\section{mRNA isolation, $R T$ and quantitative real-time PCR}

Blastocysts used for gene expression analysis were washed three times in $0.1 \%(\mathrm{w} / \mathrm{v})$ polyvinyl alcohol (PVA)/PBS solution and placed individually into $0.6 \mathrm{ml}$ siliconized Eppendorf tubes with $\sim 4 \mu \mathrm{l}$ PVA/PBS and stored at $-80^{\circ} \mathrm{C}$ until mRNA extraction. Poly $(\mathrm{A})^{+}$RNA was isolated from single blastocysts and reverse transcribed into first-strand cDNA in a $0.2 \mathrm{ml}$ reaction tube containing $20 \mu \mathrm{l}$ reaction mixture as previously described (Niemann et al. 2010, Velazquez et al. 2011). Tubes with the reaction mixture containing sterile water instead of mRNA preparation were used as controls for contamination. Tubes with the reaction mixture and $2 \mu \mathrm{l}(1 \mathrm{pg})$ rabbit globin mRNA and $9 \mu \mathrm{l}$ sterile water were prepared to produce pool of cDNA globin for quantification of globin expression used for data normalization (see below). To perform real-time PCR, wells from 96-well optical reaction plates were loaded with $20 \mu \mathrm{l} \mathrm{PCR}$ mixture containing $10 \mu \mathrm{l}$ power SYBR green PCR master mix (4367659; Applied Biosystems, Darmstadt, Germany), $0.8 \mu \mathrm{l}$ $(5 \mu \mathrm{M})$ each of the forward and reverse primers of the respective genes of interest (Table 4), $2 \mu \mathrm{l}$ cDNA $(0.2$ blastocyst equivalents) and $6.4 \mu \mathrm{l}$ sterile water. Amplification was carried out in an ABI 7500 Fast Real-Time System (Applied Biosystems; Velazquez et al. 2011). Post-PCR dissociation melting curve analyses were carried to determine the specificity of the PCR-amplified products. Raw gene expression data for target genes and globin were obtained with the Sequence Detection Software 1.3.1 (Applied Biosystems) based on standard curve dilution series 
Table 4 Primers used for real-time PCR.

\begin{tabular}{|c|c|c|c|c|c|}
\hline \multirow{3}{*}{$\frac{\text { Genes }}{I G F 1 R}$} & \multicolumn{2}{|c|}{ Primer sequences and positions } & \multirow{2}{*}{$\begin{array}{c}\begin{array}{c}\text { Annealing } \\
\text { temperature }\left({ }^{\circ} \mathrm{C}\right)\end{array} \\
60\end{array}$} & \multirow{2}{*}{$\begin{array}{c}\begin{array}{c}\text { Fragment } \\
\text { size }\end{array} \\
72\end{array}$} & \multirow{3}{*}{$\begin{array}{c}\begin{array}{c}\text { Accession } \\
\text { number }\end{array} \\
X M \_606794.3\end{array}$} \\
\hline & Forward (1068-1090) & ССТCATCAGCTTCACCGTCTACT & & & \\
\hline & Backward (1139-1121) & GCGTCCTGCCСGTCATACT & & & \\
\hline \multirow[t]{2}{*}{ IGFBP3 } & Forward (731-752) & ААСТTСТССТСТGАGTCCAAGC & 60 & 210 & NM_174556.1 \\
\hline & Backward (941-921) & CGTACTTATCCACACACCAGC & & & \\
\hline \multirow[t]{2}{*}{ TP53 } & Forward (720-739) & TTTACGCGCGGAGTATTTGG & 60 & 57 & NM_174201.2 \\
\hline & Backward (776-756) & GGCACCACCACACTGTGTCTA & & & \\
\hline \multirow[t]{2}{*}{$A K T 1$} & Forward (368-385) & GCTCACCCGGCGAGAACT & 60 & 108 & AY781100.1 \\
\hline & Backward (457-475) & CTTTGCCCAGCAGCTTCAG & & & \\
\hline \multirow[t]{2}{*}{$S L C 2 A 1$} & Forward (894-914) & CAGGAGATGAAGGAGGAGAGC & 60 & 258 & NM_174602.2 \\
\hline & Backward (1131-1151) & CACAAATAGCGACACGACAGT & & & \\
\hline \multirow[t]{2}{*}{$S L C 2 A 3$} & Forward (127-149) & GTTGCTACCATAGGCTCTTTCCA & 60 & 65 & AY033938 \\
\hline & Backward (173-192) & GATCGCCTCAGGAGCATTGA & & & \\
\hline \multirow[t]{2}{*}{$S L C 2 A B$} & Forward (1441-1461) & GCATCTTCGGTGTCCTTTTCA & 60 & 80 & AY208940 \\
\hline & Backward (1501-1521) & CAAAATGGGCTGTGATTTGCT & & & \\
\hline
\end{tabular}

(1:5) of cDNA from 60 blastocysts and pooled globin respectively (Niemann et al. 2010, Velazquez et al. 2011). Data were then transferred to Microsoft Excel and the relative mRNA abundance was calculated by dividing the target gene expression value by the amount of globin mRNA expressed in each sample (globin added as external standard during RNA extraction). To normalize data to embryo cell number, the relative abundance of each transcript in individual embryos was divided by the mean total cell number (Table 2) and multiplied by 100 (Block et al. 2008). Individual blastocysts were analyzed and each analysis was repeated 7-18 times.

\section{Immunofluorescence}

Immunostaining of TP53 and IGF1R was carried out with a validated protocol for bovine embryos (Velazquez et al. 2011). Briefly, zona-intact blastocysts were fixed (4\% paraformaldehyde) and permeabilized (0.5\% Triton X-100) followed by blocking with $10 \%$ newborn calf serum (B15-001, PAA Laboratories $\mathrm{GmbH}$ ) for $1 \mathrm{~h}$ at room temperature. Blocked embryos were incubated overnight at $4{ }^{\circ} \mathrm{C}$ with the primary antibody. The TP53 and IGF1R antibodies (Rabbit polyclonal, 9282; Cell Signalling Technology, Inc., Frankfurt, Germany) were diluted 1:100 and 1:50 respectively (Rabbit polyclonal, PAI-14212; Dianova, Hamburg, Germany). Embryos were then incubated with the Alexa Fluor 488-conjugated secondary antibody $(1: 100$; Invitrogen, Ltd) for $2 \mathrm{~h}$ in the dark at room temperature. Embryos from different cows were incubated in drops of equal volume obtained from the same antibody preparation. Embryos were counterstained with propidium iodide $(\mathrm{Pl}, 50 \mu \mathrm{l} / \mathrm{ml}$, P4170; Sigma-Aldrich, Steinheim, Germany) and mounted individually on glass microscope slides with vectashield antifade mounting medium $(\mathrm{H}-1000$; Vector Laboratories, Burlingame, CA, USA). In vitro-produced embryos (Velazquez et al. 2011) not incubated with the primary antibody served as negative controls. Embryos were analyzed by confocal laser-scanning microscopy (CLSM) with a Zeiss LSM 510 microscope (Carl Zeiss Microlmaging $\mathrm{GmbH}$, Göttingen, Germany) using a Plan-Apochromat $20 \times / 0.75$ objective. Alexa Fluor 488 and PI were detected with Argon (excitation wavelength at $488 \mathrm{~nm}$ ) and Helium (excitation wavelength at $543 \mathrm{~nm}$ ) lasers respectively. Optical sections of
$1.98 \mu \mathrm{m}$ thickness were made at $4 \mu \mathrm{m}$ intervals through the whole embryo and analyzed with the LSM Image Browser software (Carl Zeiss Microlmaging $\mathrm{GmbH}$ ). The total cell number was recorded. All embryos were scanned under the same confocal settings. Fluorescence intensity of individual embryos was assessed in one central optical section displaying both the ICM and the TE by marking and extracting six small areas of equal size. Fluorescence intensity is reported as signal strength as previously described (Velazquez et al. 2011).

\section{Analysis of IGF1 in plasma and ULF}

ULF samples were homogenized in $200 \mu \mathrm{l}$ PBS including a protease inhibitor cocktail (complete mini, Roche Diagnostics) with ceramic beads using a MagnaLizer (Roche) and directly placed on ice. For IGF1 extraction, $200 \mu \mathrm{l} \mathrm{HCl} /$ ethanol $(12.5 \mathrm{ml} 2 \mathrm{M} \mathrm{HCl} / 87.5 \mathrm{ml}$ absolute ethanol) was added to $20 \mu \mathrm{l}$ plasma or uterine fluid $(20 \mu \mathrm{l}$ from the $200 \mu \mathrm{l}$ homogenization buffer solution plus the unknown amount of uterine fluid from the uterus) and placed on a shaker for $30 \mathrm{~min}$ at room temperature. TRIS buffer ( $100 \mu \mathrm{l} ; 5.5 \mathrm{~g}$ in $50 \mathrm{ml}$ sterile water) were added and vortexed vigorously. The extract was centrifuged at $10000 \mathrm{~g}$ for $15 \mathrm{~min}$ at $4{ }^{\circ} \mathrm{C}$ and frozen at $-20^{\circ} \mathrm{C}$ overnight. The next day, $200 \mu$ l were taken from the supernatant and dried for $1 \mathrm{~h}$ in a SpeedVac concentrator to remove the ethanol. The lyophilizate was then diluted with $200 \mu$ l sterile water, from which $20 \mu$ l were taken for analysis with ELISA. Samples were measured in duplicates from one extraction. Standards and samples were diluted in assay buffer containing $0.1 \%$ gelatin. Plates were coated with goat-antirabbit IgG (own production, Technical University of Munich) and blocked with $0.5 \%$ casein (Vector SP-5020). Rabbit polyclonal antibody (provided by Prof. Schams, Technical University of Munich) was added to the plate. Samples were incubated overnight at $6-8{ }^{\circ} \mathrm{C}$. Thereafter, biotinylated IGF1 (Novozymes GroPep, Adelaide, Australia) was added and incubated for $6 \mathrm{~h}$ at $6-8{ }^{\circ} \mathrm{C}$. Plates were then decanted, followed by addition of streptavidin-peroxidase conjugate solution (Sigma-Aldrich) in each well and incubation for $15 \mathrm{~min}$ at room temperature. After washing the plates four times, substrate solution (Sigma-Aldrich) was added. The reaction was stopped after 45 min using sulfuric acid (Sigma-Aldrich). 
The absorption was photometrically determined at $450 \mathrm{~nm}$. The lower detection limit was $200 \mathrm{pg} / \mathrm{ml}$, and intra- and interassay coefficients of variation were $<10 \%$.

\section{Analysis of leptin in plasma}

The concentrations of leptin were measured by ELISA (Sauerwein et al. 2004) using ovine recombinant leptin (Gertler et al. 1998) as standard. The intra- and interassay coefficients of variations were 3.6 and $7.8 \%$ respectively. The minimal detection level of the assay was $0.3 \mathrm{ng} / \mathrm{ml}$.

\section{Statistical analysis}

Data were analyzed with SigmaStat 2.0 (Jandel Scientific, San Rafael, CA, USA). Parametric (t-test) and non-parametric (Mann-Whitney $U$ test) tests were used as appropriate (i.e. depending on normality of data). Proportions were analyzed by $\chi^{2}$ test. Associations between variables were tested by regression analysis. Differences in embryo yields were tested only in cows that responded to superovulation (i.e. two or more corpora lutea at the time of embryo recovery). Both mean \pm S.E.M. and median are reported unless otherwise indicated. A value of $P \leq 0.05$ was considered to be statistically significant.

\section{Declaration of interest}

The authors declare that there is no conflict of interest that could be perceived as prejudicing the impartiality of the research reported.

\section{Funding}

M A Velazquez was in the PhD program of the University of Veterinary Medicine, Hannover, Germany and was supported by the German Academic Exchange Service (DAAD).

\section{References}

Abbott DH, Dumesic DA, Levine JE, Dunaif A \& Padmanabhan V 2006 Animal models and fetal reprogramming of the polycystic ovary syndrome. In Androgen Excess Disorders in Women: Polycystic Ovary Syndrome and Other Disorders, pp 259-272. Eds R Azziz, JE Nestler \& D Dewailly. Totowa, NJ: Humana Press.

Adamiak SJ, Mackie K, Watt RG, Webb R \& Sinclair KD 2005 Impact of nutrition on oocyte quality: cumulative effects of body composition and diet leading to hyperinsulinemia in cattle. Biology of Reproduction 73 918-926. (doi:10.1095/biolreprod.105.041483)

Adams GP \& Pierson RA 1995 Bovine model for study of ovarian follicular dynamics in humans. Theriogenology 43 113-120. (doi:10.1016/0093691X(94)00015-M)

Agarwal SK, Vogel K, Weitsman SR \& Magoffin DA 1999 Leptin antagonizes the insulin-like growth factor-I augmentation of steroidogenesis in granulosa and theca cells of the human ovary. Journal of Clinical Endocrinology and Metabolism 84 1072-1076. (doi:10.1210/jc.84.3. 1072)

Arlotto T, Schwartz JL, First NL \& Leidfried-Rutledge ML 1996 Aspects of follicle and oocyte stage that affect in vitro maturation and development of bovine oocytes. Theriogenology 45 943-956. (doi:10.1016/0093691X(96)00024-6)
Baracaldo MI, Martinez MF, Adams GP \& Mapletoft RJ 2000 Superovulatory response following transvaginal follicle ablation in cattle. Theriogenology 53 1239-1250. (doi:10.1016/S0093-691X(00)00268-5)

Basset NS, Breier BH, Hodgkinson SC, Davis SR, Henderson HV \& Gluckman PD 1990 Plasma clearance of radiolabelled IGF-1 in the late gestation ovine fetus. Journal of Developmental Physiology $\mathbf{1 4}$ 73-79.

Bertolini M, Beam SW, Shim H, Bertolini LR, Moyer AL, Famula TR \& Anderson GB 2002 Growth, development, and gene expression by in vivo- and in vitro-produced day 7 and 16 bovine embryos. Molecular Reproduction and Development 63 318-328. (doi:10.1002/ mrd.90015)

Block J, Wrenzycki C, Niemann H, Herrmann D \& Hansen PJ 2008 Effects of insulin-like growth factor-1 on cellular and molecular characteristics of bovine blastocysts produced in vitro. Molecular Reproduction and Development 75 895-903. (doi:10.1002/mrd.20826)

Blockeel C, Mock P, Verheyen G, Bouche N, Le Goff Ph, Heyman Y, Wrenzycki C, Höffmann K, Niemann H, Haentjens P et al. 2009 An in vivo culture system for human embryos using an encapsulation technology: a pilot study. Human Reproduction 24 790-796. (doi:10. 1093/humrep/dep005)

Brewer CJ \& Balen AH 2010 The adverse effects of obesity on conception and implantation. Reproduction 140 347-364. (doi:10.1530/REP-090568)

Bungartz L \& Niemann H 1994 Assessment of the presence of a dominant follicle and selection of dairy cows suitable for superovulation by a single ultrasound examination. Journal of Reproduction and Fertility 101 583-591. (doi:10.1530/jrf.0.1010583)

Chagas LM, Bass JJ, Blache D, Burke CR, Kay JK, Lindsay DR, Lucy MC, Martin GB, Meier S, Rhodes FM et al. 2007 Invited review: new perspectives on the roles of nutrition and metabolic priorities in the subfertility of high producing dairy cows. Journal of Dairy Science $\mathbf{9 0}$ 4022-4032. (doi:10.3168/jds.2006-852)

Chi MM, Schlein AL \& Moley KH 2000 High insulin-like growth factor 1 (IGF-1) and insulin concentrations trigger apoptosis in the mouse blastocyst via down-regulation of the IGF-1 receptor. Endocrinology 141 4784-4792. (doi:10.1210/en.141.12.4784)

Dayi A, Bediz CS, Musal B, Yilmaz O, Comlekci A, Celiloglu M \& Cimrin D 2005 Comparison of leptin levels in serum and follicular fluid during the oestrous cycle in cows. Acta Veterinaria Hungarica 53 457-467. (doi:10. 1556/AVet.53.2005.4.6)

Edmonson AJ, Lean IJ, Weaver LD, Farver T \& Webster G 1989 A body condition score chart of Holstein dairy cows. Journal of Dairy Science $\mathbf{7 2}$ 68-78. (doi:10.3168/jds.S0022-0302(89)79081-0)

Ehrhardt RA, Slepetis RM, Siegal-Willot J, Van Amburg ME, Bell AW \& Boisclair YR 2000 Development of a specific radioimmunoassay to measure physiological changes of circulating leptin in cattle and sheep. Journal of Endocrinology 166 519-528. (doi:10.1677/joe.0.1660519)

Einer-Jensen N \& Hunter RHF 2005 Counter-current transfer in reproductive biology. Reproduction 129 9-18. (doi:10.1530/rep.1.00278)

Eng GS, Sheridan RA, Wyman A, Chi MMY, Bibee KP, Jungheim ES \& Moley KH 2007 AMP kinase activation increases glucose uptake, decreases apoptosis, and improves pregnancy outcome in embryos exposed to high IGF-I concentrations. Diabetes 56 2228-2234. (doi:10. 2337/db07-0074)

Essah PA, Cheang KI \& Nestler JE 2004 The pathophysiology of miscarriage in women with polycystic ovary syndrome. Review and proposed hypothesis of mechanisms involved. Hormones 3 221-227.

Fair T, Hyttel P \& Greve T 1995 Bovine oocyte diameter in relation to maturational competence and transcriptional activity. Molecular Reproduction and Development 42 437-442. (doi:10.1002/mrd.108 0420410)

Firth SM \& Baxter RC 2002 Cellular actions of the insulin-like growth factor binding proteins. Endocrine Reviews 23 824-854. (doi:10.1210/er.20010033)

Gertler A, Simmons J \& Keisler DH 1998 Large-scale preparation of biologically active recombinant ovine obese protein (leptin). FEBS Letters 422 137-140. (doi:10.1016/S0014-5793(97)01613-X)

Guha N, Sönksen PH \& Holt RIG 2009 IGF-1 abuse in sport: current knowledge and future prospects for detection. Growth Hormone \& IGF Research 19 408-411. (doi:10.1016/j.ghir.2009.04.017) 
Guler HP, Zapf J, Schmid C \& Froesch ER 1989 Insulin-like growth factors I and II in healthy man. Estimation of half-lives and production rates. Acta Endocrinologica 121 753-758.

Honnens A, Niemann H, Herzog K, Paul V, Meyer HHD \& Bollwein H 2009 Relationships between ovarian blood flow and ovarian response to eCG-treatment of dairy cows. Animal Reproduction Science $\mathbf{1 1 3}$ 1-10. (doi:10.1016/j.anireprosci.2008.05.077)

Hu W 2009 The role of p53 gene family in reproduction. Cold Spring Harbor Perspectives in Biology 1 a001073. (doi:10.1101/cshperspect. a001073)

Hu W, Feng Z, Teresky AK \& Levine AJ 2007 p53 regulates maternal reproduction through LIF. Nature 450 721-724. (doi:10.1038/ nature05993)

Huang HF, Wang B, Yang XF, Luo Q \& Sheng JZ 2005 Nitric oxide mediates inhibitory effect of leptin on insulin-like growth factor I augmentation of $17 \beta$-estradiol production in human granulosa cells. Biology of Reproduction 72 102-106. (doi:10.1095/biolreprod.104.032078)

Jousan FD, Oliveira LJ \& Hansen PJ 2008 Short-term culture of in vitro produced bovine preimplantation embryos with insulin-like growth factor-I prevents heat shock-induced apoptosis through activation of the phosphatidylinositol 3-kinase/Akt pathway. Molecular Reproduction and Development 75 681-688. (doi:10.1002/mrd.20830)

Karamouti M, Kollia P, Kallitsaris A, Vamvakopoulos N, Kollios G \& Messinis IE 2008 Growth hormone, insulin-like growth factor I, and leptin interaction in human cultured lutein granulosa cells steroidogenesis. Fertility and Sterility 90 (Supplement 4) 1444-1500. (doi:10.1016/ j.fertnstert.2007.08.076)

Katagiri S, Moon YS \& Yuen BH 1996 The role for the uterine insulin-like growth factor I in early embryonic loss after superovulation in the rat. Fertility and Sterility 65 426-436.

Katagiri S, Ma S, Yuen BH \& Moon YS 1997 Role for insulin-like growth factor I in the regulation of electrolyte composition of uterine luminal fluid. Journal of Reproduction and Fertility 109 115-120. (doi:10.1530/ jrf.0.1090115)

Keim AL, Chi MMY \& Moley KH 2001 Hyperglycemia-induced apoptotic cell death in the mouse blastocyst is dependant on expression of p53. Molecular Reproduction and Development 60 214-224. (doi:10.1002/ mrd.1080)

Kwintkiewicz J \& Giudice LC 2009 The interplay of insulin-like growth factors, gonadotropins, and endocrine disruptors in ovarian follicular development and function. Seminars in Reproductive Medicine 27 43-51. (doi:10.1055/s-0028-1108009)

Lazzari G, Wrenzycki C, Herrmann D, Duchi R, Kruip T, Niemann H \& Galli C 2002 Cellular and molecular deviations in bovine in vitroproduced embryos are related to the large offspring syndrome. Biology of Reproduction 67 767-775. (doi:10.1095/biolreprod.102.004481)

Leroy JLMR, Opsomer G, De Vliegher S, Vanholder T, Goossens L, Geldhof A, Bols PEJ, de Kruif A \& Van Soom A 2005 Comparison of embryo quality in high-yielding dairy cows, in dairy heifers and in beef cows. Theriogenology 64 2022-2036. (doi:10.1016/j.theriogenology. 2005.05.003)

Lim KT, Jang G, Ko KH, Lee WW, Park HJ, Kim JJ, Lee SH, Hwang WS, Lee BC \& Kang SK 2007 Improved in vitro bovine embryo development and increased efficiency in producing viable calves using defined media. Theriogenology 67 293-302. (doi:10.1016/j.theriogenology.2006.07. 011)

Lloyd RE, Romar R, Matás C, Gutiérrez-Adán A, Holt WV \& Coy P 2009 Effects of oviductal fluid on the development, quality, and gene expression of porcine blastocysts produced in vitro. Reproduction 137 679-687. (doi:10.1530/REP-08-0405)

Matwee C, Kamaruddin M, Betts DH, Basrur PK \& King AW 2001 The effects of antibodies to heat shock protein 70 in fertilization and embryo development. Human Reproduction 7 829-837. (doi:10.1093/molehr/7. 9.829)

McCaffery FH, Leask R, Riley SC \& Telfer EE 2000 Culture of bovine preantral follicles in a serum-free system: markers for assessment of growth and development. Biology of Reproduction 63 267-273. (doi:10. 1095/biolreprod63.1.267)

Moley KH, Bibee K, Wyman A \& Eng GS 2005 IGF-1 induced blastocyst apoptosis is p53 dependant. Fertility and Sterility $\mathbf{8 4}$ (Supplement 1) 388. (doi:10.1016/j.fertnstert.2005.07.1015)
Muñoz-Gutiérrez M, Findlay PA, Adam CL, Wax G, Campbell BK, Rendall NR, Khalid M, Forsberg M \& Scaramuzzi RJ 2005 The ovarian expression for mRNAs for aromatase, IGF-I receptor, IGF-binding protein-2, -4 , and -5 , leptin and leptin receptor in cycling ewes after three days of leptin infusion. Reproduction 130 869-881. (doi:10.1530/ rep.1.00557)

Nasu K, Itoh H, Yuge A, Kawano Y \& Narahara H 2006 Insulin-like growth factor-I regulates vascular endothelial growth factor secretion by human oviductal epithelial cells and stromal fibroblasts. Journal of the Society for Gynecologic Investigation 13 368-371. (doi:10.1016/j.jsgi.2006.03. 007)

Nicholas B, Alberio R, Fouladi-Nashta AA \& Webb R 2005 Relationship between low-molecular-weight insulin-like growth factor-binding proteins, caspase- 3 activity, and oocyte quality. Biology of Reproduction 72 796-804. (doi:10.1095/biolreprod.104.036087)

Niemann H, Carnwath JW, Herrmann D, Wieczoreck G, Lemme E, LucasHahn A \& Olek S 2010 DNA methylation patterns reflect epigenetic reprogramming in bovine embryos. Cellular Reprogramming 12 33-42. (doi:10.1089/cell.2009.0063)

Oropeza A, Wrenzycki C, Herrmann D, Hadeler KG \& Niemann H 2004 Improvement of the developmental capacity of oocytes from prepubertal cattle by intraovarian insulin-like growth factor- 1 application. Biology of Reproduction 70 1634-1643. (doi:10.1095/biolreprod.103.025494)

Otoi T, Yamamoto K, Koyama N, Tachikawa S \& Suzuki T 1997 Bovine oocyte diameter in relation to developmental competence. Theriogenology $\mathbf{4 8}$ 769-774. (doi:10.1016/S0093-691X(97)00300-2)

Paria BC, Ma WG, Tan J, Raja S, Das SK, Dey SK \& Hogan BLM 2001 Cellular and molecular responses of the uterus to embryo implantation can be elicited by locally applied growth factors. PNAS 98 1047-1052. (doi:10.1073/pnas.98.3.1047)

Pasquali R \& Gambineri A 2008 Mechanisms and treatment of obesity in polycystic ovary syndrome. In Polycystic Ovary Syndrome: Current Controversies, from the Ovary to the Pancreas, pp 217-240. Eds A Dunaif, RJ Chang, S Franks \& RS Legro. Totowa, NJ: Humana Press.

Paye JMD \& Forsten-Williams K 2006 Regulation of insulin-like growth factor-I (IGF-1) delivery by IGF binding proteins and receptors. Annals of Biomedical Engineering 34 618-632. (doi:10.1007/s10439-005-9064-6)

Pinto AB, Schlein AL \& Moley KH 2002 Preimplantation exposure to high insulin-like growth factor I concentrations results in increased resorption rates in vivo. Human Reproduction 17 457-462. (doi:10.1093/humrep/ 17.2.457)

Premoli AC, Santana LF, Ferriani RA, de Moura MD, De Sá MFS \& dos Reis RM 2005 Growth hormone secretion and insulin-like growth factor- 1 are related to hyperandrogenism in nonobese patients with polycystic ovary syndrome. Fertility and Sterility 83 1852-1855. (doi:10. 1016/j.fertnstert.2004.10.057)

Rho GJ, Balasubramanian S, Kim DS, Son WJ, Cho SR, Kim JG, Kumar MB \& Choe SY 2007 Influence of in vitro oxygen concentrations on preimplantation embryo development, gene expression and production of Hanwoo calves following embryo transfer. Molecular Reproduction and Development 74 486-496. (doi:10.1002/mrd.20502)

Rodier F, Campisi J \& Bhaumik D 2007 Two faces of p53: aging and tumor suppression. Nucleic Acids Research 35 7475-7484. (doi:10.1093/nar/ gkm744)

Sauerwein H, Heintges U, Hennies M, Selhorst T \& Daxenberger A 2004 Growth hormone induced alterations of leptin serum concentrations in dairy cows as measured by a novel enzyme immunoassay. Livestock Production Science 87 189-195. (doi:10.1016/j.livprodsci.2003.08.001)

Sawai K 2009 Studies on gene expression in bovine embryos derived from somatic cell nuclear transfer. Journal of Reproduction and Development 55 11-16. (doi:10.1262/jrd.20131)

Schmid P, Lorenz A, Hameister H \& Montenarh M 1991 Expression of p53 during mouse embryogenesis. Development 113 857-865.

Sepp-Lorenzino L 1998 Structure and function of the insulin-like growth factor I receptor. Breast Cancer Research and Treatment 47 235-253. (doi:10.1023/A:1005955017615)

Shahiduzzaman AKM, Beg MA, Palhao MP, Siddiqui MAR, Shamsuddin M \& Ginther OJ 2010 Stimulation of the largest subordinate follicle by intrafollicular treatment with insulin-like growth factor 1 is associated with inhibition of the dominant follicle in heifers. Theriogenology $\mathbf{7 4}$ 194-201. (doi:10.1016/j.theriogenology.2010.02.001) 
Shing CM, Hunter DC \& Stevenson LM 2009 Bovine colostrum supplementation and exercise performance: potential mechanisms. Sports Medicine 39 1033-1054. (doi:10.2165/11317860-00000000000000)

Siddiqui MAR, Gastal EL, Gastal MO, Almamun M, Beg MA \& Ginther OJ 2009 Relationship of vascular perfusion of the wall of the preovulatory follicle to in vitro fertilisation and embryo development in heifers. Reproduction 137 689-697. (doi:10.1530/REP-08-0403)

Silfen ME, Denburg MR, Manibo AM, Lobo RA, Jaffe R, Ferin M, Levine LS \& Oberfield SE 2003 Early endocrine, metabolic, and sonographic characteristics of polycystic ovary syndrome (PCOS): comparison between nonobese and obese adolescents. Journal of Clinical Endocrinology and Metabolism 88 4682-4688. (doi:10.1210/jc.2003-030617)

Sonksen PH 2001 Insulin, growth hormone and sports. Journal of Endocrinology 170 13-25. (doi:10.1677/joe.0.1700013)

Spicer LJ, Chamberlain CS \& Francisco CC 2000 Ovarian action of leptin: effects on insulin-like growth factor-I-stimulated function of granulosa and theca cells. Endocrine 12 53-59. (doi:10.1385/ENDO: $12: 1: 53)$

Stringfellow DA \& Seidel SM 1998 Manual of the International Embryo Transfer Society. 3rd edn. Champaign, IL: International Embryo Transfer Society (IETS).

Thierry van Dessel HJH, Lee PDK, Faessen G, Fauser BCJM \& Giudice LC 1999 Elevated serum levels of free insulin-like growth factor I in polycystic ovary syndrome. Journal of Clinical Endocrinology and Metabolism 84 3030-3035. (doi:10.1210/jc.84.9.3030)

Thomas FH, Campbell BK, Armstrong DG \& Telfer EE 2007 Effects of IGF-1 bioavailability on bovine preantral follicular development in vitro. Reproduction 133 1121-1128. (doi:10.1530/REP-06-0382)

Torchinsky A \& Toder V 2010 Mechanisms of the embryo's response to embryopathic stressors: a focus on p53. Journal of Reproductive Immunology 85 76-80. (doi:10.1016/j.jri.2010.01.003)

Toyoshima M 2009 Analysis of p53 dependant damage response in spermirradiated mouse embryos. Journal of Radiation Research 50 11-17. (doi:10.1269/jrr.08099)

Velazquez MA, Spicer LJ \& Wathes DC 2008 The role of endocrine insulin-like growth factor-I (IGF-1) in female bovine reproduction. Domestic Animal Endocrinology 35 325-342. (doi:10.1016/j.domaniend.2008.07.002)
Velazquez MA, Zaraza J, Oropeza A, Webb R \& Niemann H 2009 The role of IGF-1 in the in vivo production of bovine embryos from superovulated donors. Reproduction 137 161-180. (doi:10.1530/REP08-0362)

Velazquez MA, Parrilla I, Van Soom A, Verberckmoes S, Kues W \& Niemann H 2010 Sampling techniques for oviductal and uterine luminal fluid in cattle. Theriogenology 73 758-767. (doi:10.1016/j.theriogenology. 2009.07.004)

Velazquez MA, Herrmann D, Kues WA \& Niemann H 2011 Increased apoptosis in bovine blastocysts exposed to high levels of IGF1 is not associated with down-regulation of the IGF1 receptor. Reproduction 141 91-103. (doi:10.1530/REP-10-0336)

Wang HS \& Chard T 1999 IGFs and IGF-binding proteins in the regulation of human ovarian and endometrial function. Journal of Endocrinology 161 1-13. (doi:10.1677/joe.0.1610001)

Wang TH, Chang CL, Wu HM, Chiu YM, Chen CK \& Wang HS 2006 Insulinlike growth factor-II (IGF-II), IGF-binding proteins-3 (IGFBP3), and IGFBP-4 in follicular fluid are associated with oocyte maturation and embryo development. Fertility and Sterility 86 1392-1401. (doi:10.1016/ j.fertnstert.2006.03.064)

Zachow RJ \& Magoffin DA 1997 Direct intraovarian effects of leptin: impairment of the synergistic action of insulin-like growth factor-I on follicle-stimulating hormone-dependent estradiol- $17 \beta$ production by rat ovarian granulosa cells. Endocrinology 138 847-850. (doi:10.1210/en. 138.2.847)

Zaraza J, Oropeza A, Velazquez MA, Korsawe K, Herrmann D, Carnwath JW \& Niemann H 2010 Developmental competence and mRNA expression of preimplantation in vitro-produced embryos from prepubertal and postpubertal cattle and their relationship with apoptosis after intraovarian administration of IGF-1. Theriogenology 74 75-89. (doi:10.1016/j.theriogenology.2009.11.033)

Received 13 December 2010

First decision 21 February 2011

Revised manuscript received 28 April 2011

Accepted 4 May 2011 